Article

\title{
Baicalein Inhibits Stx1 and 2 of EHEC: Effects of Baicalein on the Cytotoxicity, Production, and Secretion of Shiga Toxins of Enterohaemorrhagic Escherichia coli
}

\author{
Pham Thi Vinh ${ }^{1, *}$, Yui Shinohara ${ }^{1}$, Akifumi Yamada ${ }^{1}$, Hoang Minh Duc ${ }^{1}$, \\ Motokazu Nakayama $^{2}$, Tadahiro Ozawa ${ }^{3}$, Jun Sato ${ }^{2}$, Yoshimitsu Masuda ${ }^{1}$, Ken-Ichi Honjoh ${ }^{1}$ \\ and Takahisa Miyamoto ${ }^{1}$ \\ 1 Division of Food Science \& Biotechnology, Department of Bioscience and Biotechnology, \\ Faculty of Agriculture, Graduate School, Kyushu University, 744 Motooka, Nishi-ku, \\ Fukuoka 819-0395, Japan \\ 2 Global R\&D-Safty Science, Kao Corporation, 2606, Akabane, Ichikai-machi, Haga-gun, \\ Tochigi 321-3497, Japan \\ 3 Bioscience Research, Kao Corporation, 2606, Akabane, Ichikai-machi, Haga-gun, Tochigi 321-3497, Japan \\ * Correspondence: phamthivinh@tuaf.edu.vn; Tel.: +81-80-2671-4144
}

Received: 25 July 2019; Accepted: 27 August 2019; Published: 29 August 2019

check for updates

\begin{abstract}
Shiga toxin-producing enterohaemorrhagic Escherichia coli (EHEC) O157:H7 is an important foodborne pathogen. Baicalein (5,6,7-trihydroxylflavone), a flavone isolated from the roots of Scutellaria baicalensis, is considered as a potential antibacterial agent to control foodborne pathogens. Among seven compounds selected by in silico screening of the natural compound database, baicalein inhibited the cytotoxicity of both Shiga toxins 1 and 2 (Stx1 and Stx2) against Vero cells after pretreatment at $0.13 \mathrm{mmol} / \mathrm{L}$. In addition, baicalein reduced the susceptibility of Vero cells to both Stx1 and Stx2. Real-time qPCR showed that baicalein increased transcription of stx 1 but not of st $x 2$. However, baicalein had no effects on production or secretion of Stx1 or Stx2. Docking models suggested that baicalein formed a stable structure with StxB pentamer with low intramolecular energy. The results demonstrate that inhibitory activity of baicalein against the cytotoxicity of both Stx1 and Stx2 might be due to of the formation of a binding structure inside the pocket of the Stx1B and Stx $2 B$ pentamers.
\end{abstract}

Keywords: baicalein; Stx; inhibition; cytotoxicity; enterohaemorrhagic Escherichia coli

Key Contribution: This research suggested that baicalein is one of the potential candidates for antivirulence strategies against enterohemorrhagic Escherichia coli infection.

\section{Introduction}

Enterohaemorrhagic Escherichia coli (EHEC) causes foodborne illness and can lead to haemorrhagic colitis (bloody diarrhoea) and potentially fatal haemolytic uraemic syndrome (HUS) [1]. Shiga toxin (Stx) is an important virulence factor of EHEC, also known as verocytotoxin or vero toxin. There are two subgroups of Stx, namely Stx1 and Stx2, which are found in different combinations in EHEC isolates [2]. Stx is one of the AB-5 family of toxins, consisting of a pentameric B subunit noncovalently bound to an enzymatically active A subunit. The Stx receptors are glycolipids of the globo-series, of which globotriaosylceramides (Gb3s) is the primary receptor found on the surface of vascular endothelial cells and kidney epithelial cells. However, Stx subtypes have been shown to bind with different affinities to multiple glycolipid receptors. Sx1a preferentially binds to Gb3, with detectable binding 
to globotetraosylceramide (Gb4) whereas Stx2a strongly binds to Gb3 and marginally binds to Gb4 [3]. Stx2e binds to both Gb3 and Gb4, and also to the Forssman glycosphingolipid [4]. The Stx pentameric B subunit interacts with Gb3 and induces membrane invagination, leading to the internalization of the toxin. The internalized Stxs inhibit protein synthesis, leading to cell death. Recently, however, Lee et al. (2019) reviewed the multifunctionality of Stxs, which not only inhibits protein synthesis but also induces apoptosis in different cell types [5].

Bacterial infections are commonly treated with antibiotics. However, antibiotic therapy in the treament of EHEC infection is still controversial because the increase in Stx production and secretion leads to the risk of HUS development [6-8]. Certain drugs commonly used in the clinic to treat EHEC-infected patients are not recommended, such as antibiotics, antimotility agents, narcotics, and non-steroidal anti-inflammatory agents [9]. In addition, Hiroi et al. (2012) indicated that EHEC strains isolated from humans have shown increased resistance to one or variety antibiotics [10]. Clearly, the demand for the development of novel therapies to prevent or treat EHEC infections is increasing.

Plant polyphenols and plant extracts, including polyphenols, have been reported to inhibit cholera [11] and Stx2 toxins [12], among others. Furthermore, polyphenols have almost no toxicity to humans and some natural phenolic compounds could be developed as effective drugs. For example, the extracts of plants and mushrooms are cost-effective alternatives for antibiotics to enhance innate immunity in chickens [13]. Phytochemicals, including plant polyphenols, have shown inhibitory effects on verocytotoxin-producing E. coli O157:H7 [14]. The combination of phenolic compounds and antibitotics has also shown synergistic effects against both Staphylococcus aureus and Escherichia coli [15]. Further studies in this area would be helpful to develop the new methods for the treatment of bacterial infections.

We previously investigated the inhibition effects of green tea polyphenols on Stxs at low concentrations using purified catechins. In the previous study [16], we showed that the cytotoxicity of Stx1 was reduced by pretreatment with gallocatechin gallate (GCg) and epigallocatechin gallate (EGCg). In contrast, catechins and theaflavin did not inhibit the cytotoxicity of Stx2 [16]. These results suggest that the tertiary structure of gallocatechin, which is from the galloyl group, is important for Stx1 cytotoxicity inhibition.

In this study, we examined the effects of phenolic compounds, screened by docking simulation from the natural compounds database, on the cytotoxicity of Stx. Among the compounds selected by the in silico screening, baicalein reduced the cytotoxicity of Stx1 and Stx2. The effects of baicalein, which showed the strongest inhibitory activity against Stx, were investigated on the protection of Vero cells against Stx, and the production of Stxs by EHEC.

\section{Results}

\subsection{Effects of Baicalein on the Cytotoxicity of Stx}

The natural compounds selected from the in silico screening are listed in Table 1. The Stx was preincubated with or without each of the compounds at $100 \mathrm{mg} / \mathrm{L}$ before addition to the Vero cells culture. After incubation at $37^{\circ} \mathrm{C}$ for $24 \mathrm{~h}$, the viability of Vero cells was determined. The cytotoxicity of Stx 1 and Stx 2 decreased after preincubation with baicalein, in contrast to preincubation with the other compounds (Figure S1). 
Table 1. Candidate compounds for Stx inhibitors selected from a collection of purified natural products isolated from plants (MEGxp; AnalytiCon Discover) by docking simulation.

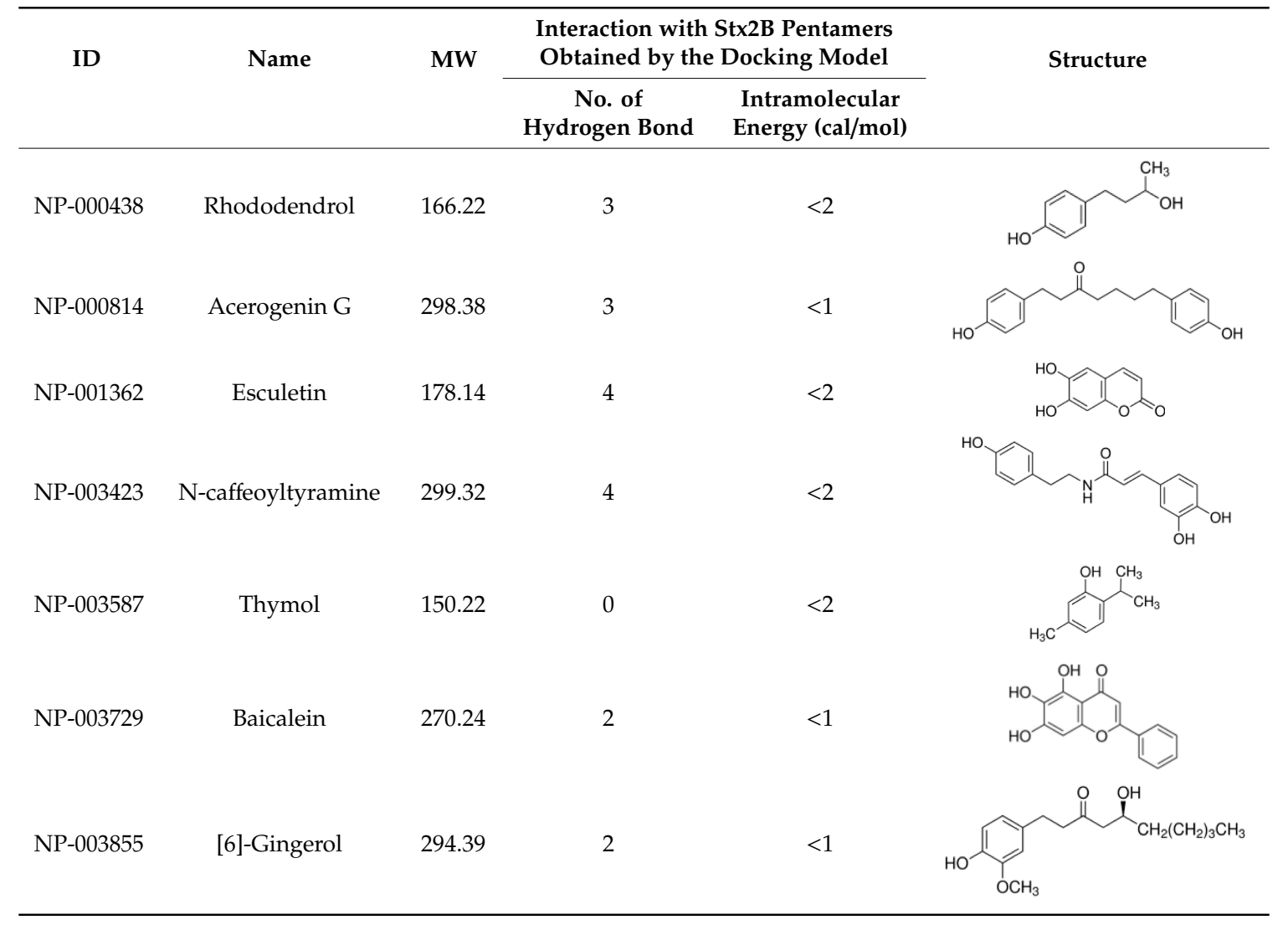

The effects of baicalein on the cytotoxicity of Stx1 and Stx2 were further investigated in detail. Baicalein was mixed with the Stx preparations with different Stx concentrations and incubated for $1 \mathrm{~h}$. The mixture was then added to the Vero cell culture. Figure 1 shows the effects of baicalein on the cytotoxicity of Stx 1 and Stx2. The viability of Vero cells decreased with increasing concentration of Stx1 and Stx2, both in the absence and presence of baicalein. However, the cytotoxicity of both Stx1 and Stx2 was significantly reduced $(p<0.01)$ by the pretreatment with baicalein (Figure 1A,B). At $0.13 \mathrm{mmol} / \mathrm{L}$, baicalein significantly reduced the cytotoxicity of $\mathrm{Stx} 1$ at concentrations ranging from 0.5 to $33.3 \mathrm{ng} / \mathrm{mL}$, and to that of Stx2 from 2.1 to $533.3 \mathrm{ng} / \mathrm{mL}$. The results clearly demonstrate that baicalein inhibited the cytotoxicity of both Stx1 and Stx2. 
(A) Stx1

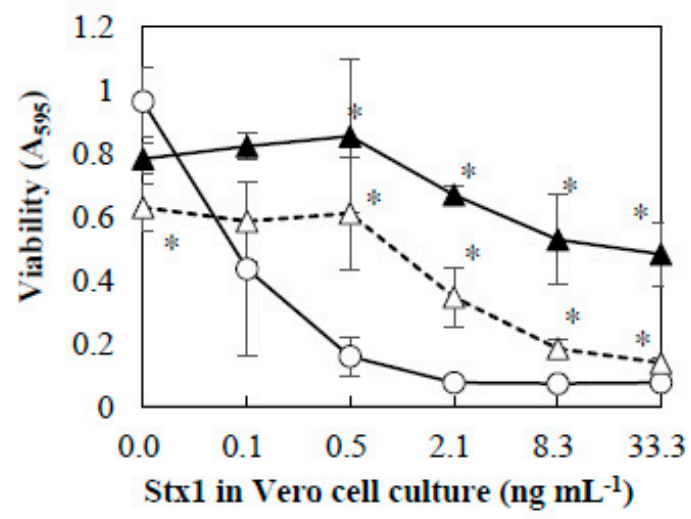

(B) Stx2

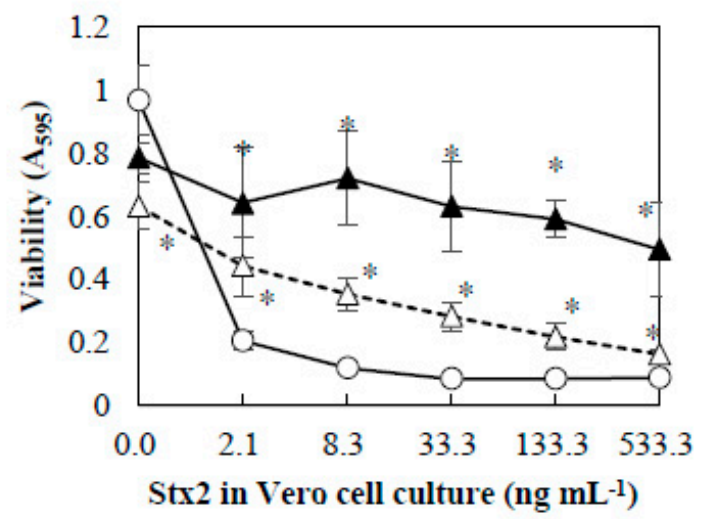

Figure 1. Effects of baicalein on the cytotoxicity of Stx1 and Stx2. Stx1 (A) and Stx2 (B) preparations respectively containing Stx1 and Stx 2 were mixed with baicalein and incubated for $1 \mathrm{~h}$ at $37{ }^{\circ} \mathrm{C}$. After the incubation, the mixture was added to the culture of Vero cells. The final concentrations of baicalein in the culture were $0(\bigcirc), 0.027(\triangle)$, and $0.13(\Delta) \mathrm{mmol} / \mathrm{L}$. Cell viability was determined by using MTT Cell Proliferation Assay after the cultivation at $37^{\circ} \mathrm{C}$ for $48 \mathrm{~h}$. Values are average \pm SD for three separate experiments. ${ }^{*}, p<0.01$.

\subsection{Protective Effect of Baicalein on Vero Cells against Stx}

To determine the protective effects of baicalein on Vero cells against Stx, Vero cells were preincubated with baicalein and then Stx preparations were added to the cells. Figure 2 shows the effects of Stx preparations on the viability of Vero cells pretreated with baicalein. In the absence or presence of baicalein, increasing the concentration of Stx 1 and Stx 2 decreased the viability of Vero cells. However, even in the presence of Stx 1 or Stx2, the viability of Vero cells pretreated with baicalein was significantly higher than that of control without the pretreatment (Figure 2A,B). It seems that baicalein protected Vero cells from the cytotoxicity of both Stx1 and Stx2.

(A) Stx1

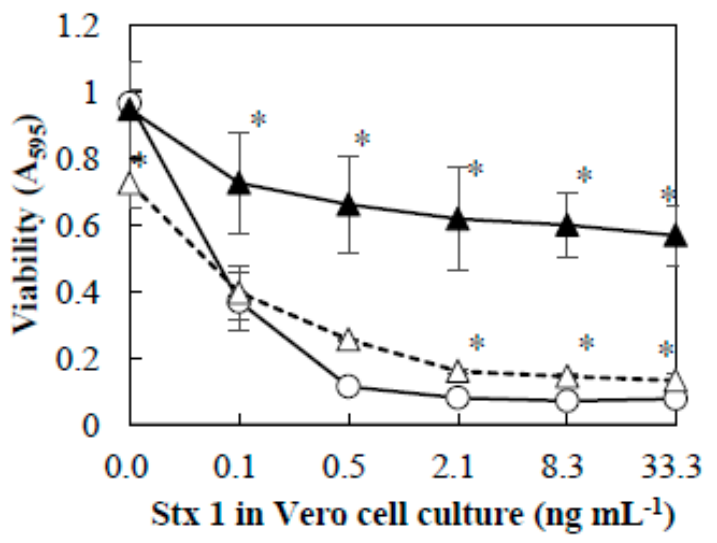

(B) Stx2

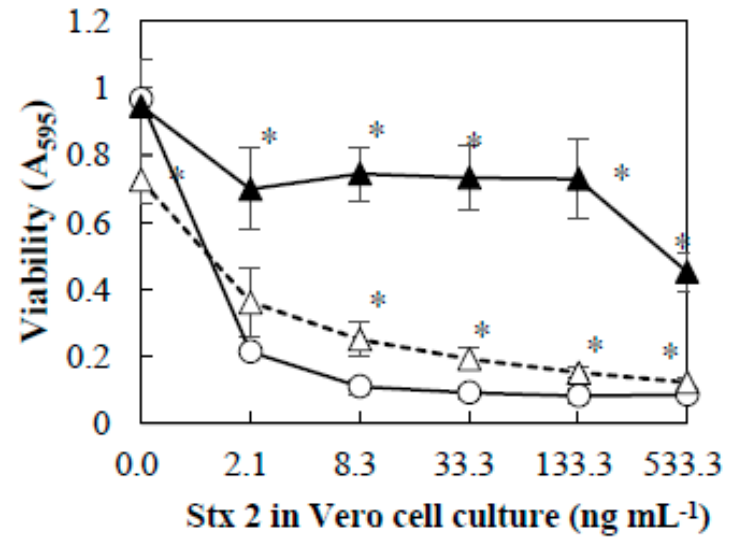

Figure 2. Effects of Stx1and Stx2 on viability of Vero cells pretreated with baicalein. Baicalein was added to Vero cell culture and incubated for $1 \mathrm{~h}$ at $37^{\circ} \mathrm{C}$. After the incubation, Stx1 (A) and Stx2 (B) preparations were added to the culture. The final concentrations of baicalein in the culture were $0(\bigcirc)$, $0.027(\triangle)$, and $0.13(\triangle) \mathrm{mmol} / \mathrm{L}$. After cultivation at $37^{\circ} \mathrm{C}$ for $48 \mathrm{~h}$, cell viability was determined by using MTT Cell Proliferation Assay. Values are average \pm SD for three separate experiments. ${ }^{*}, p<0.01$.

\subsection{Effects of Baicalein on Production of Stx by EHEC}

The transcriptional levels of $s t x$ were evaluated by real-time qPCR. The relative quantity of transcripts of stx 1 and stx 2 was compared between the cells treated with and without baicalein 
and MMC. Figure 3 shows the effects of baicalein and MMC on the transcription of stx genes. After treatment with baicalein, the transcription level of stx 1 was enhanced to 2.9-fold that of negative control (Figure 3A), whereas no significant difference in the transcription level of stx 2 was obtained (Figure 3B). However, in both the extracellular and intracellular samples prepared from E. coli O157:H7 treated with baicalein, amounts of both Stx1 and Stx2 were similar to those of the samples without baicalein treatment (Table 2). For the positive control, MMC induced the transcription level of both st $x 1$ and st $x 2$ by 17.8 - and 6.8 -fold compared to the negative control, respectively (Figure $3 \mathrm{~A}, \mathrm{~B}$ ).
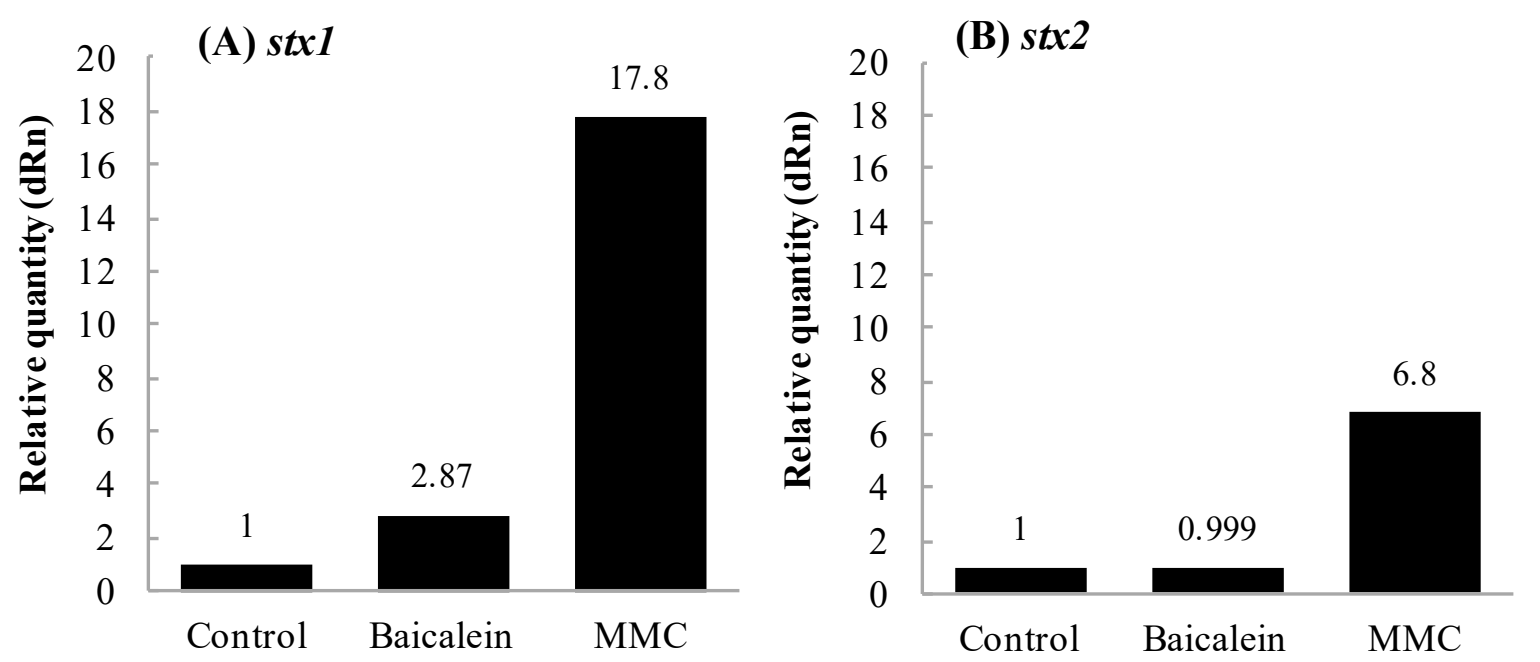

Figure 3. Effects of baicalein on the transcription of stx in Escherichia coli O157:H7. E. coli O157:H7 No. 33 (stx1+, st $x 2-)$ and O157:H7 No. 36 (st $x 1-$, st $x 2+)$ strains were cultured until OD660 = 0.6 in the presence and absence of baicalein at $0.38 \mathrm{mmol} / \mathrm{L}$. Amounts of transcripts of stx1 (A) and stx2 (B) were determined by real-time qPCR assay. Values are average of two separate experiments.

Table 2. Effects of baicalein on tx production after 24-h incubation.

\begin{tabular}{ccccc}
\hline \multirow{2}{*}{ Samples } & \multicolumn{3}{c}{ Stx Concentration $(\mathrm{ng} / \mathrm{mL})$} \\
\cline { 3 - 5 } & & Control & Baicalein & Mitomycin C \\
\hline \multirow{2}{*}{ Stx1 } & Extracellular & 400 & 400 & 1600 \\
\cline { 2 - 5 } & Intracellular & 50 & 50 & $\mathrm{ND}$ \\
\hline \multirow{2}{*}{ Stx2 } & Extracellular & 200 & 200 & 204800 \\
\cline { 2 - 5 } & Intracellular & 3 & 3 & $\mathrm{ND}$
\end{tabular}

**: Stx concentration was determined by RPLA assay. Values are average of two separate experiments. ND: not determined.

To evaluate the effects of baicalein on the secretion of Stx in detail, cytotoxicity of the extracellular and intracellular Stx preparations was investigated. As shown in Figure 4, increasing the concentration of extracellular and intracellular Stx1 and Stx2 decreased the viability of Vero cells (Figure 4A,B). There was no significant difference in viability between Vero cells in the presence of Stx prepared from E. coli O157:H7 cultured in the presence and absence of baicalein. The results suggest that baicalein had no effects on the secretion of both Stx1 and Stx2. 


\section{(A) Stx1}
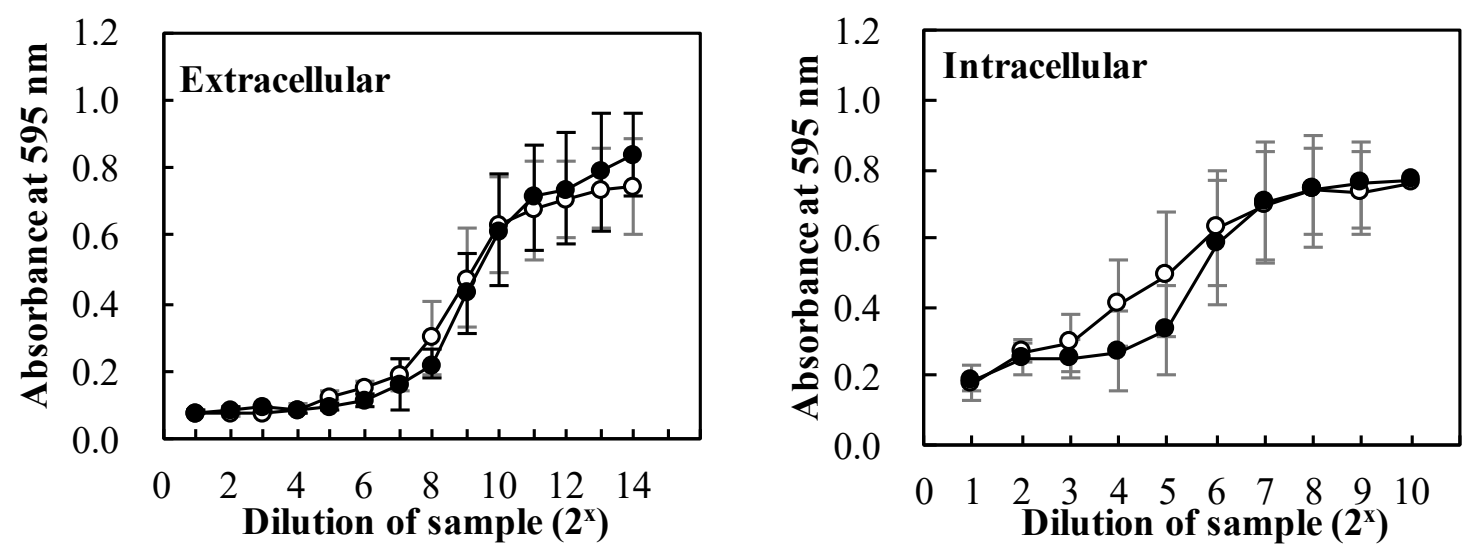

(B) Stx2
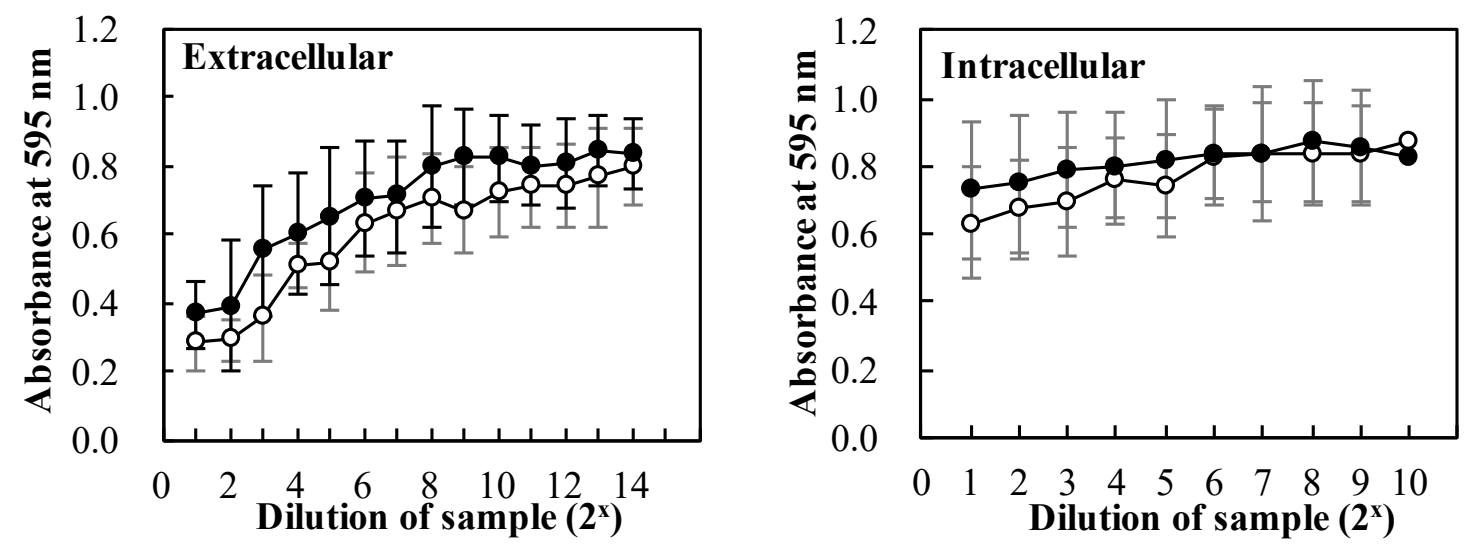

Figure 4. Effects of baicalein on secretion of Stx by Escherichia. coli O157:H7. E. coli O157:H7 No. $33($ st $x 1+$, st $x 2-)$ and O157:H7 No. $36(s t x 1-$, st $x 2+)$ cultures were cultured in the presence $(\bullet)$ and absence $(\bigcirc)$ of baicalein for $24 \mathrm{~h}$ at $37^{\circ} \mathrm{C}$. After the incubation, extracellular and intracellular Stx1 (A), extracellular and intracellular Stx2 (B) preparations were respectively prepared from the cultures. The cytotoxicity of the preparations was determined on Vero cells. Cell viability was determined by using MTT Cell Proliferation Assay. The values are the average of three separate experiments.

\subsection{Interaction of Baicalein with Stx1B and Stx2B Pentamers}

Figure 5 shows the docking models of baicalein bound to the pockets of Stx $1 \mathrm{~B}$ and Stx2B pentamers. According to the conformation of the Stx1B and Stx2B pentamers, the potential site for binding to baicalein was estimated to be from Trp33 to Gly46 (Trp-Asn-Leu-Gln-Ser-Leu-Leu-Leu-Ser-Ala-Gln-Ile-Thr-Gly) in the Stx1B monomer and from Trp32 to Gly45 (Trp-Asn-Leu-Gln-Pro-Leu-Leu-Leu-Ser-Ala-Gln-Leu-Thr-Gly) in the Stx2B monomer $[17,18]$. A-E and A-J were respectively named for each the monomers of Stx1B and Stx2B pentamers [16]. The results show that baicalein bound to the side chains of amino acids facing inside the pocket of the Stx1B pentamer by forming two hydrogen bonds at (1)Ser42 and (2)Ser42 of Monomer B (Figure 5A). Similarly, for the case of Stx2B pentamer, baicalein formed 1 hydrogen bond at (1)Ser41 of Monomer $\mathrm{J}$ (Figure 5B). The lowest intramolecular energy of the bonds of baicalein with the Stx1B and Stx2B pentamers was 1.8 and $0.2 \mathrm{kcal} / \mathrm{mol}$, respectively. These results indicate that baicalein formed a complex structure with both the Stx1B (pocket size: $778 \AA^{3}$ ) and Stx2B pentamers (pocket size: $475 \AA^{3}$ ). 
<smiles>O=c1cc(-c2ccccc2)oc2cc(O)c(O)c(O)c12</smiles>

(A) Stx1B and Baicalein

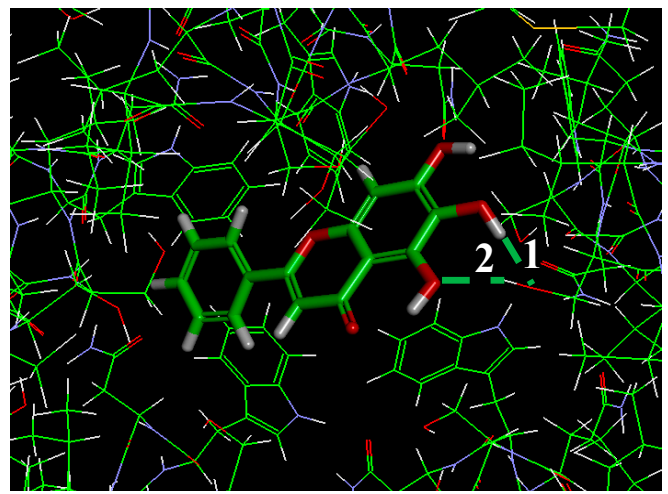

(B) Stx2B and Baicalein

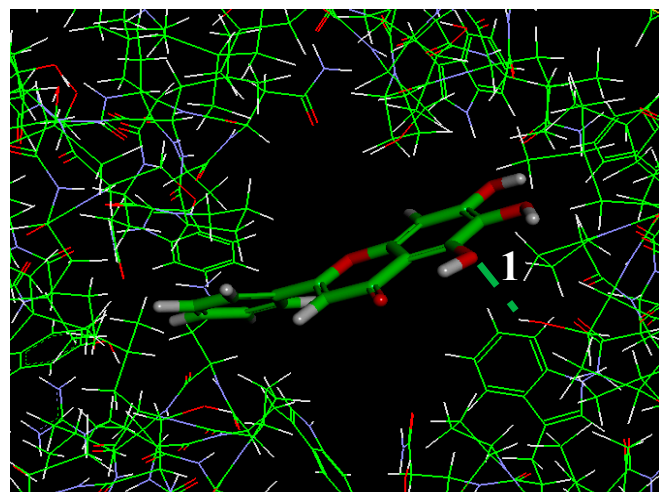

Figure 5. Docking models of baicalein bound to the pockets of Stx1B and Stx2B pentamers. Hydrogen bonds formed between baicalein and amino acids facing inside the pockets of Stx1B and Stx2B pentamers are white numbers. (A) Model showing two hydrogen bonds formed between baicalein and side chains of amino acid facing inside the pocket of the Stx1B pentamer at Ser42 and Ser42 of Monomer B. (B) Model showing one hydrogen bond formed between baicalein and side chain of amino acid of the Stx2B pentamer at Ser41 of Monomer J.

\section{Discussion}

Baicalein is a major component of Scutellaria baicalensis, a Chinese herb. In addition to its inhibitory effect on lipoxygenase and reverse transcriptase, it was found to have antioxidant, neuroprotective, antibacterial, antiviral, and antifungal activities [19-21]. Baicalein has also been reported to inhibit the biofilm formation of Candida albicans [22], and to induce apoptosis in a variety of human cancer cell lines [23-26]. Baicalein has been reported to induce cancer cell death and proliferation retardation by inhibiting CDC2 kinase and survivin [27]. Baicalein has been shown to inhibit enzymes of the cytochorome P450 system (CYP2C9) which metabolizes drugs in the body by binding to the substrate site of the enzyme [28]. Furthermore, baicalin, a parental compound of baicalein, significantly reduced the activity of Stx 2 which induced lethality in mice [29]. The protection effects of baicalin on the cell against EHEC infection were clarified by Zhang et al. (2017) [30]. To the best of our knowledge, however, there are currently no reports on the inhibition effect of baicalein on the cytotoxicity of both Stx1 and Stx2. Therefore, further research with purified Stxs is needed to confirm the results of the in silico study. This is the first report that demonstrates that baicalein inhibited the cytotoxicity of both Stx1 and Stx2, possibly by forming a binding structure inside the pocket of the Stx1B and Stx2B pentamers.

The extent of the inhibitory activity of baicalein against the cytotoxicity of Stx1 was similar to that of EGCg, which did not inhibit the cytotoxicity of Stx2 [16]. Docking simulation suggests that baicalein formed two hydrogen bonds with amino acids inside the pocket of the Stx1B pentamer, with the low intramolecular energy of $1.8 \mathrm{kcal} / \mathrm{mol}$, but it formed only one hydrogen bond with the low intramolecular energy of $0.2 \mathrm{kcal} / \mathrm{mol}$ with the Stx2B pentamer (Figure 5). It has been previously reported that 6 hydrogen bonds were formed in the interaction between EGCg and Stx2B pentamer, 
with the lowest intramolecular energy of $5.2 \mathrm{kcal} / \mathrm{mol}$ [16]. Since the molecular weight of baicalein (MW: 270.2) was much lower than that of EGCg (MW: 458.4), baicalein seemed to form a stable hydrogen bond with the side chain of amino acid facing inside the pocket of the Stx2B pentamer. This bond was formed with the lowest intramolecular energy when compared to the bonds of EGCg with the Stx2B pentamer even though the number of hydrogen bonds with the pentamer was lower than that of EGCg.

Furthermore, baicalein protected Vero cells from cytotoxicity of both Stx1 and Stx2. It has been reported that baicalein protected human hepatoma cells against attacks by cancer cells due to its ability to prevent the adhesion, migration, and invasion of cancer cells [31]. In addition, baicalein has been shown to protect human skin cells againts oxidative stress by Ultraviolet B (UVB) via preventing reactive oxygen species and absorbing UVB radiation [32]. Cariddi et al. (2015) reported that caffeic acid, a polyphenol, protected Vero cells from the cytotoxicity of ochratoxin A by altering principally the lysosomal function in Vero cells [33]. It seems that baicalein protects Vero cells from cytotoxicity of Stx by binding to the surface of the cytoplasmic membrane of the cell and altering the function of the membrane. At $0.13 \mathrm{mmol} / \mathrm{L}$, the preincubation with bacialein reduced Vero cells sensitivity to Stx1 and Stx2 by approximately 6- and 8-fold, respectively (Figure 2). Cell protection against Stx of other compounds has also been reported in many studies. For exemple, the protective effect of 4 phenylacetyl-Arg-Val-Arg-4-amidinobenzylamide at concentrations of $25 \mu \mathrm{mol} / \mathrm{L}$ on Hep-2 cells againsts Stx increased by 6-fold [34], while chloroquine at concentration $25 \mu \mathrm{mol} / \mathrm{L}$ reduced Hep-2 cells sensitivity to Stx 2 by 20 -fold [35]. Although these compounds protected cells at the lower concentration, they have not been used in humans beacause of their toxicity [36,37].

The inhibition effects of baicalein on the cytotoxicity of Stx were determined (Figures 1 and 2). As the results in Figures 1 and 2 show, there was a decrease in inhibition of bacalein at $0.027 \mathrm{mmol} / \mathrm{L}$ in Figure 2 compared to the results in Figure 1. One of the possible explanations for this could be that the binding of Stx to the surface of Vero cell was more preferential than the binding of baicalein to StxB pentamers

In addition, baicalein significantly inhibited the expression of CTX-M-1 mRNA expression in Klebsiella pneumoniae strains [38]. We therefore performed experiments designed to determine the effects of baicalein on st $x 1$ and st $x 2$ transcription compared to negative (water) and positive (MMC) controls. In our study, treatment with MMC strongly increased the transcription of both st $x 1$ and st $x 2$, while baicalein slightly increased the transcription of stx 1 but not stx2 (Figure 3). Stx production of EHEC has been reported to be controlled by several factors, such as growth phase, reactive oxygen species, quorum sensing, $\mathrm{H}_{2} \mathrm{O}_{2}$, and neutrophils [39-41]. Specifically, Stx production by EHEC increase at the stationary growth $[39,42]$. It is also known that Stx production was regulated by phage through the amplification of gene copy number and toxin release [42]. Wagner et al. (2002) suggested that damage of bacterial cells could lead to the release of Stx by the absence of phage-mediated lysis in E. coli O26:H19 [43]. Moreover, baicalein inhibited growth of Staphylococcus aureus by the aggregation of bacterial cells and damaging the bacterial cell membrane [44]. In addition, it has also been reported that the increase in membrane fluidity was associated with the increase of Stx secretion in E. coli O157:H7 [45]. Wu et al. (2013) reported that baicalein exhibited antibacterial activity against E. coli by lowering membrane fluidity of the cells [46]. Together with the above findings, the results in this study suggest that baicalein did not affect the growth and membrane fluidity of E. coli O157:H7 at $0.38 \mathrm{mmol} / \mathrm{L}$, though it reduced cytotoxicity of Stx and protected Vero cells at the lower concentration $(0.13 \mathrm{mmol} / \mathrm{L})$. However, our data showed that baicalein had no significant effects on the secretion of both Stx1 and Stx2 (Figure 4). This is an advantage of using baicalein to treat EHEC infections over antibiotics.

Some studies suggested that baicalein may be developed as a potential candidate for treatment of various disease models such as diabetes, cardiovascular diseases, inflammatory bowel diseases, gout and rheumatoid arthritis, asthma, encephalomyelitis, and carcinogenesis, neurological diseases, Alzheimer's and Parkinson's disease [47,48]. In 2019, Javed and Ojha reported that oral administration 
of baicalein for treatment Parkinson's disease was safe for human [49]. It has also been reported that a mixture of baicalein in the dietary metabolic management of osteoarthritis was safe for human consumption [50]. Together with these facts, our results suggest that baicalein is one of the potential candidates for antivirulence strategies against EHEC infection. However, further research is still required to carefully evaluate the application of baicalein in the clinic.

\section{Materials and methods}

\subsection{Analysis of Interaction between StxB Pentamers and Natural Products}

The interaction between the compounds in the MEGxp, the library of plant-derived natural products, and the Stx2 B subunit pentamer was analysed using the CDOCKER module of the Discovery Studio software (c41b1, Accelrys, Inc., San Diego, CA 92121, USA), on a Windows XP PC. The crystal structure of the Stx2 B subunit pentamer [17] registered in the Protein Data Bank as PDB ID: 3MXG was used in the calculations. Docking simulations were conducted with the compound positioned in the center of the Stx2 B subunit pentamer pore. Docking was performed by using molecular dynamics simulations. The conditions used for the screening of the natural products were as follows: the molecular weight was less than that of the EGCg (MW: 458.4), and the lowest intramolecular energy (strain energy + electrostatic energy) was less than $2 \mathrm{kcal} / \mathrm{mol}$. The molecular structure of the binding between the B subunit pentamers and the compounds was determined using the free energy minimization method [51]. The compounds selected from the in silico screening were obtained from NAMIKI SHOJI Co., Ltd., Tokyo, Japan.

\subsection{Preparation of Stx 1 and $S t x 2$}

The preparations containing Stx1, Stx 2 and no Stx preparations were respectively prepared from the cultures of E. coli O157:H7 No. 33 (stx1+, stx2-), O157:H7 No. 184 (stx1-, stx2+) and O157:H7 No. 37 (stx1-, st $x 2-)$, following the previously described procedure by Miyamoto et al. (2014) [16]. These E. coli O157:H7 strains were cultured in Luria Broth (LB, Becton Dickinson Company, Franklin Lakes, NJ, USA) at $37^{\circ} \mathrm{C}$ for $24 \mathrm{~h}$ with shaking, then polymyxin $\mathrm{B}$ was added to the culture and incubated at $37^{\circ} \mathrm{C}$ for $1 \mathrm{~h}$. The final concentration of polymyxin B in the culture was $5000 \mathrm{U} / \mathrm{mL}$. After centrifugation at $3300 \times \mathrm{g}$ for $15 \mathrm{~min}$ at $4{ }^{\circ} \mathrm{C}$ of $25 \mathrm{~mL}$ of the culture, the supernatants were recovered. The Millex-GP $0.22 \mu \mathrm{m}$ filter (Merck Millipore, Billerica, MA, USA) was used to filter the supernatants, then the filtrates were used as Stx preparations.

In these preparations, the titers of Stx were determined using the VTEC-RPLA Seiken test (Denka Seiken Co., Ltd., Tokyo, Japan), following the manufacturer's instructions. The titers of Stx1 and Stx2 were determined to be 256 and $<2$ in the Stx 1 , and $<2$ and 1024 in the Stx2 preparations, and $<2$ and $<2$ in the preparation without Stx, respectively. Titer of 128 was obtained for both purified Stx 1 and Stx 2 at $100 \mathrm{ng} / \mathrm{mL}$ and the concentrations of Stx 1 and Stx 2 were calculated according to the manufacturer's instructions.

\subsection{Determination of Stx-inhibitory Activity of Baicalein}

The effects of baicalein (NAMIKI SHOJI Co., Ltd., Tokyo, Japan) on the cytotoxicity of Stx were determined according to the previously reported method [16]. Vero cells were purchased from Cell Bank (RIKEN BioResource Center, Tsukuba, Ibaraki, Japan). The cell viability was determined using the MTT Cell Proliferation Assay Kit (Cayman Chemical Company, Ann Arbor, MI, USA), following the supplier's instruction. Medium was removed and fresh 5\% FBS-MEM-E medium $(10 \mu \mathrm{L})$ was added to the well. An amount of $12 \mathrm{mmol} / \mathrm{L}$ MTT stock solution $(10 \mu \mathrm{L})$ was added to each well. The medium was removed after incubation at $37^{\circ} \mathrm{C}$. To resolve the MTT formazan crystals formed, $100 \mu \mathrm{L}$ of Cell-Based Assay Buffer was added to the well. Medium alone was used as a negative control. Absorbance at $595 \mathrm{~nm}$ was measured using Microplate Reader Model 680 (Bio-Rad Laboratories Inc., Hercules, CA, USA). A value OD at $595 \mathrm{~nm}$ was used to show cell viability. 
To determine the inhibitory activity of baicalein, various concentrations of the Stx preparations were incubated with baicalein before addition to the Vero cell culture. The final concentration of baicalein in the culture was 0.027 and $0.13 \mathrm{mmol} / \mathrm{L}$. Three replicates of the treatments were carried out per experiment and the values were shown as an average $\pm S D$ of $A_{595}$. The statistical significance of the OD values was calculated by the Student's $t$-test.

\subsection{Determination of Protective Effect of Baicalein on Vero cells against Stx}

The protective effects of baicalein on Vero cells against Stx were determined. Vero cell culture $(0.1 \mathrm{~mL})$ was added to each well of 96-well microtiter plate at $2 \times 10^{4}$ cells per well and cultured for $24 \mathrm{~h}$. One hundred microliters of baicalein at 0.08 and $0.4 \mathrm{mmol} / \mathrm{L}$ in PBS were added to each well and incubated for $1 \mathrm{~h}$ at $37^{\circ} \mathrm{C}$. Stx preparations $(0.1 \mathrm{~mL})$ were added to each well, then further cultured for $48 \mathrm{~h}$ at $37^{\circ} \mathrm{C}$ in $5 \% \mathrm{CO}_{2}$ incubator. The final concentrations of baicalein in the culture were 0.027 and $0.13 \mathrm{mmol} / \mathrm{L}$. For control, PBS was used instead of the polyphenol. The viability of the Vero cells was determined using the MTT Cell Proliferation Assay Kit (Cayman Chemical Company, Ann Arbor, MI, USA), according to the supplier's instruction.

Three replicates of the treatments were carried out per experiment. The values were reported as an average $\pm S D$ of $A_{595}$. The statistical significance of the OD values was calculated by the Student's T-test.

\subsection{Determination of Transcription of Stx, Production and Secretion of StxF}

To determine the effects of baicalein on transcription, production, and secretion of stx, E. coli O157:H7 No. 33 (stx1+, st $x 2-)$ and O157:H7 No. 36 (stx1-, st $x 2+)$ were used. These bacteria were inoculated into LB and cultured overnight at $37^{\circ} \mathrm{C}$ with shaking. This bacterial culture was diluted in sterilized water to attain $\mathrm{OD}_{660}=0.1$ (bacterial concentration of ca. $10^{8} \mathrm{CFU}$ per $\mathrm{mL}$ ). The culture $(1 \mathrm{~mL})$ was centrifuged at $60,000 \times g$ for $5 \mathrm{~min}$ at $25^{\circ} \mathrm{C}$ and the supernatants were recovered. The precipitate was resuspended in $1 \mathrm{~mL}$ sterile water and then 10-dilutied to a final concentration of ca. $10^{6} \mathrm{CFU} / \mathrm{mL}$ for use in subsequent experiments. One $\mathrm{mL}$ of $0.8 \mathrm{mmol} / \mathrm{L}$ baicalein solution was mixed with $1 \mathrm{~mL}$ of $2 \times \mathrm{LB}$ and $100 \mu \mathrm{L}$ of each of the diluted cultures in a test tube and the mixture was incubated at $37^{\circ} \mathrm{C}$ with shaking at $130 \mathrm{rpm}$. The final concentration of baicalein in the mixture was $0.38 \mathrm{mmol} / \mathrm{L}$. For control, sterile water was used instead of baicalein solution. To know the effects of Mitomycin C (MMC, Wao Pure Chemicals, Inc., Tokyo, Japan), LB (2 mL) and each of the diluted cultures $(100 \mu \mathrm{L})$ were mixed and then incubated at $37^{\circ} \mathrm{C}$ with shaking to reach $\mathrm{OD}=0.1$ before adding with MMC (final concentration of $0.2 \mathrm{mg} / \mathrm{mL}$ ). To determine the effect of baicalein and MMC on transcription of $s t x$, cells were harvested at $\mathrm{OD}_{660} \approx 0.6$. To determine the effects of baicalein on the production and secretion of Stx, the mixtures were incubated for $24 \mathrm{~h}$.

To determine the amounts of transcript of $s t x$, cells were harvested by centrifugation at $8000 \times g$ for $5 \mathrm{~min}$ at $4{ }^{\circ} \mathrm{C}$. The precipitates were suspended in sterile water and the suspension was centrifuged at $8000 \times \mathrm{g}$ for $5 \mathrm{~min}$ at $4{ }^{\circ} \mathrm{C}$ and the supernatants were removed. This process was repeated three times to wash the cells. A mixture of $700 \mu \mathrm{L}$ Dw-saturated phenol and $700 \mu \mathrm{L}$ TES buffer pre-warmed at $65{ }^{\circ} \mathrm{C}$ was added to the cell precipitate. After vortexing, the cell suspension was incubated for $40 \mathrm{~min}$ at $65{ }^{\circ} \mathrm{C}$ with occasional vortexing. The cell suspension was then placed on ice for $2 \mathrm{~min}$ and centrifuged at $17,860 \times \mathrm{g}$ for $10 \mathrm{~min}$ at $4{ }^{\circ} \mathrm{C}$. Eight hundred $\mu \mathrm{L}$ of TRIzol ${ }^{\circledR} \mathrm{LS}$ was added to the aqueous phase, and the mixture was vortexed and placed on ice for $5 \mathrm{~min}$. After $200 \mu \mathrm{L}$ of chloroform was added to the mixture, the mixture was vortexed, placed on ice for $5 \mathrm{~min}$, and centrifuged at $17,860 \times g$ for $10 \mathrm{~min}$ at $4{ }^{\circ} \mathrm{C}$. To the aqueous phase recovered, $600 \mu \mathrm{L}$ of chloroform was added, and the mixture was vortexed, placed on ice for $5 \mathrm{~min}$, and centrifuged at $17,860 \times \mathrm{g}$ for $10 \mathrm{~min}$ at $4{ }^{\circ} \mathrm{C}$. Six hundred $\mu \mathrm{L}$ of isopropanol was added to the aqueous phase recovered and the mixture was vortexed, placed on ice for $10 \mathrm{~min}$, and centrifuged at $17,860 \times \mathrm{g}$ for $10 \mathrm{~min}$ at $4{ }^{\circ} \mathrm{C}$. The precipitate was dissolved in $200 \mu \mathrm{L}$ of DEPC- treated deionized water. Six hundred $\mu \mathrm{L}$ of $99 \%$ ethanol and $20 \mu \mathrm{L}$ of $3 \mathrm{M} \mathrm{NaOAc}\left(\mathrm{pH} 5.2\right.$ ) were added and the mixture was stored at $-80^{\circ} \mathrm{C}$ for $60 \mathrm{~min}$. After centrifugation $\left(17,860 \times g, 15 \mathrm{~min}, 4^{\circ} \mathrm{C}\right)$, the precipitate was dried at room temperature 
for $10 \mathrm{~min}$ and dissolved in $20 \mu \mathrm{L}$ of DEPC-treated deionized water. Quality and quantity of total RNA were checked with a spectrophotometer. The RNA samples were treated with RNase-Free DNase set (QIAGEN, Dusseldorf, Germany), purified and concentrated using the RNeasy Mini Kit (QIAGEN, Dusseldorf, Germany) according to the supplier's instruction. The purified RNA samples were reverse-transcribed using the ReverTra Ace ${ }^{\circledR}$ qPCR RT Master Mix (TOYOBO, Osaka, Japan) according to the supplier's instruction. For stx1, primers Stx1-F-n2 (5'-gttgcgaaggaatttacc-3') and Stx1-R-n2 (5'-gtctgtaatggagtacctattg-3'), and for stx2, Stx2-F-n2 (5'-cgacccaacaaagttatg-3'), Stx2-R-n2 (5'-gggtgtggttaataacag-3') were designed on the basis of the nucleotide sequences of stx genes (accession number: CP017444.1, CP012802.1) For the housekeeping gene, primers rrsA-F (5'-aggcttcgggttgtaaagt-3') and rrsA-R (cggggatttcacatctgact) were designed on the basis of the nucleotide sequence of $r r s A$ gene (accession number: J01859.1) PCR mixture $(20 \mu \mathrm{L})$ was consisted of $10 \mu \mathrm{L}$ of THUNDERBIRD@SYBR qPCR Mix (TOYOBO), $0.04 \mu \mathrm{L}$ of $50 \times$ ROX reference dye, $0.6 \mu \mathrm{L}$ of $10 \mu \mathrm{mol} / \mathrm{L}$ forward primer, $0.6 \mu \mathrm{L}$ of $10 \mu \mathrm{M}$ reaverse primer, $2 \mu \mathrm{L}$ of $25 \mathrm{ng} / \mu \mathrm{L} c \mathrm{cNA}$, and $6.76 \mu \mathrm{L}$ of RT-PCR grade water. Real-time PCR was conducted in the condition of initial denaturation at $95^{\circ} \mathrm{C}$ for $60 \mathrm{~s}, 40$ cycles of denaturation at $95^{\circ} \mathrm{C}$ for $15 \mathrm{~s}$, annealing at $58^{\circ} \mathrm{C}$ for $15 \mathrm{~s}$, and extension at $72{ }^{\circ} \mathrm{C}$ for $30 \mathrm{~s}$, and 1 cycle of denaturation at $95^{\circ} \mathrm{C}$ for $30 \mathrm{~s}$, annealing at $58^{\circ} \mathrm{C}$ for $30 \mathrm{~s}$, and denaturation at $95{ }^{\circ} \mathrm{C}$ for $30 \mathrm{~s}$. All PCR reactions were run on $\mathrm{M} \times 3000 \mathrm{P}^{\circledR}$ Real-Time PCR System and results were analyzed by MxPro ${ }^{\mathrm{TM}}$ Software version 3.00 (Stratagene, La Jolla, CA, USA).

To determine the effect of baicalein on the production and secretion of Stx, the mixtures were centrifuged at $3300 \times \mathrm{g}$ for $15 \mathrm{~min}$ at $4{ }^{\circ} \mathrm{C}$ after incubation for $24 \mathrm{~h}$. The supernatants were filtered through a Millex-GP filter $(0.45 \mu \mathrm{m})$ and the filtrate was used as an extracellular sample. The precipitate was washed once with PBS by centrifugation and suspended with $2 \mathrm{~mL}$ of PBS. The suspension was then centrifuged at $3300 \times g$ for $15 \mathrm{~min}$ at $4{ }^{\circ} \mathrm{C}$. The precipitate was suspended with $2 \mathrm{~mL}$ of PBS. To the suspension, polymyxin B (Pfizer Japan Inc.) was added to the culture. The final concentration of polymyxin B was $5000 \mathrm{U} / \mathrm{mL}$. The culture was incubated for $30 \mathrm{~min}$ at $37^{\circ} \mathrm{C}$ with occasional vortex and centrifuged at $3300 \times g$ for $15 \mathrm{~min}$ at $4{ }^{\circ} \mathrm{C}$. The supernatant was filtered by Millex-GP filter $(0.45 \mu \mathrm{m})$ and used as an intracellular sample. Extracellular samples were used for Stx sample in case of E. coli O157:H7 treated with MMC.

The titers of Stx in the samples were determined by using the VTEC-RPLA Seiken test kit and the concentrations of Stx 1 and Stx 2 were calculated as described above. For cytotoxicity test of the samples, Vero cell culture $(0.1 \mathrm{~mL})$ was added to each well of 96-well microtiter plate at $2 \times 10^{4}$ cells per well and cultured for $24 \mathrm{~h}$. Extracellular and intracellular samples at a different mixing ratio in PBS $(200 \mu \mathrm{L})$ were added to each well and cells were cultured for $48 \mathrm{~h}$ at $37^{\circ} \mathrm{C}$ in $5 \% \mathrm{CO}_{2}$ incubator. The MTT Cell Proliferation Assay Kit was used to determine the viability of the Vero cells as described above. Three replicates of the treatments were performed for each experiment and values were reported as average or average $\pm \mathrm{SD}$ of $\mathrm{A}_{595}$. The statistical significance of the OD values was calculated using the Student's $t$-test.

Supplementary Materials: The following are available online at http://www.mdpi.com/2072-6651/11/9/505/s1, Figure S1: Effects of polyphenols on the cytotoxicity of Stx1 and Stx2. Stx1 (A) and Stx2 (B) preparations containing Stx 1 and Stx2 at 12.5 and $50 \mathrm{mg} / \mathrm{L}$, respectively were mixed without (None) or with $100 \mathrm{mg} / \mathrm{L}$ of each of the polyphenols and incubated incubated at $37^{\circ} \mathrm{C}$ for $1 \mathrm{~h}$. After the incubation, the mixture was added to the culture of Vero cells. Cell viability was determined by using MTT Cell Proliferation Assay after cultivation at $37^{\circ} \mathrm{C}$ for $24 \mathrm{~h}$. The values are the average of two separate experiments.

Author Contributions: T.M. designed and wrote the manuscript; Y.S., A.Y., M.N., T.O. and J.S. carried out the experiment; P.T.V. wrote the manuscript; K.-I.H., Y.M. and H.M.D. worked on the manuscript.

Funding: This research received no external funding

Conflicts of Interest: The authors declare no competing financial interest. 


\section{References}

1. Croxen, M.A.; Finlay, B.B. Molecular mechanisms of Escherichia coli pathogenicity. Nat. Rev. Microbiol. 2010, 8, 26-38. [CrossRef] [PubMed]

2. Nataro, J.P.; Kaper, J.B. Diarrheagenic Escherichia coli. Clin. Microbiol. Rev. 1998, 11, 142-201. [CrossRef] [PubMed]

3. Steil, D.; Schepers, C.-L.; Pohlentz, G.; Legros, N.; Runde, J.; Humpf, H.-U.; Karch, H.; Müthing, J. Shiga toxin glycosphingolipid receptors of Vero-B4 kidney epithelial cells and their membrane microdomain lipid environment. J. Lipid Res. 2015, 56, 2322-2336. [CrossRef]

4. Müthing, J.; Meisen, I.; Zhang, W.; Bielaszewska, M.; Mormann, M.; Bauerfeind, R.; Schmidt, M.A.; Friedrich, A.W.; Karch, H. Promiscuous Shiga toxin 2e and its intimate relationship to Forssman. Glycobiology 2012, 22, 849-862. [CrossRef] [PubMed]

5. Lee, M.S.; Tesh, V.L. Roles of shiga toxins in immunopathology. Toxins 2019, 11, 1-26. [CrossRef] [PubMed]

6. Holtz, L.R.; Neill, M.A.; Tarr, P.I. Acute Bloody Diarrhea: A Medical emergency for patients of all ages. Gastroenterology 2009, 136, 1887-1898. [CrossRef] [PubMed]

7. Smith, K.E.; Wilker, P.R.; Reiter, P.L.; Hedican, E.B.; Bender, J.B.; Hedberg, C.W. Antibiotic treatment of Escherichia coli $\mathrm{O} 157$ infection and the risk of hemolytic uremic syndrome, Minnesota. Pediatric Infect. Dis. J. 2012, 31, 37-41. [CrossRef] [PubMed]

8. Agger, M.; Scheutz, F.; Villumsen, S.; Mølbak, K.; Petersen, A.M. Antibiotic treatment of verocytotoxin-producing Escherichia coli (VTEC) infection: A systematic review and a proposal. J. Antimicrob. Chemother. 2015, 70, 2440-2446. [CrossRef]

9. Tarr, P.I.; Gordon, C.A.; Chandler, W.L. Shiga-toxin-producing Escherichia coli and haemolytic uraemic syndrome. Lancet. Elsevier Ltd. 2005, 1073-1086. [CrossRef]

10. Hiroi, M.; Takahashi, N.; Harada, T.; Kawamori, F.; Iida, N.; Kanda, T.; Sugiyama, K.; Ohashi, N.; Hara-Kudo, Y.; Masuda, T. Serotype, Shiga toxin (Stx) type, and antimicrobial resistance of Stx-producing Escherichia coli isolated from humans in Shizuoka Prefecture, Japan (2003-2007). Jpn. J. Infect. Dis. 2012, 65, 198-202.

11. Morinaga, N.; Iwamarul, Y.; Yahiro, K.; Tagashira, M.; Moss, J.; Noda, M. Differential activities of plant polyphenols on the binding and internalization of cholera toxin in vero cells. J. Biol. Chem. 2005, 280, 23303-23309. [CrossRef] [PubMed]

12. Quiñones, B.; Massey, S.; Friedman, M.; Swimley, M.S.; Teter, K. Novel cell-based method to detect shiga toxin 2 from Escherichia coli O157:H7 and inhibitors of toxin activity. Appl. Environ. Microbiol. 2009, 75, 1410-1416. [CrossRef] [PubMed]

13. Lee, S.H.; Lillehoj, H.S.; Hong, Y.H.; Jang, S.I.; Lillehoj, E.P.; Ionescu, C.; Mazuranok, L.; Bravo, D. In vitro effects of plant and mushroom extracts on immunological function of chicken lymphocytes and macrophages. Br. Poult. Sci. 2010, 51, 213-221. [CrossRef] [PubMed]

14. Doughari, J.H.; Human, I.S.; Bennade, S.; Ndakidemi, P.A. Phytochemicals as chemotherapeutic agents and antioxidants: Possible solution to the control of antibiotic resistant verocytotoxin producing bacteria. J. Med. Plants Res. 2009, 3, 839-848.

15. Sanhueza, L.; Melo, R.; Montero, R.; Maisey, K.; Mendoza, L.; Wilkens, M. Synergistic interactions between phenolic compounds identified in grape pomace extract with antibiotics of different classes against Staphylococcus aureus and Escherichia coli. PLoS ONE 2017, 12, 1-15. [CrossRef] [PubMed]

16. Miyamoto, T.; Toyofuku, S.; Tachiki, N.; Kimura, E.; Zhou, T.; Ozawa, T.; Nakayamab, M.; Shigemuneb, N.; Shimatanib, K.; Tokudab, H.; et al. Specific inhibition of cytotoxicity of Shiga-like toxin 1 of enterohemorrhagic Escherichia coli by gallocatechin gallate and epigallocatechin gallate. Food Control 2014, 42, 263-269. [CrossRef]

17. Fraser, M.E.; Fujinaga, M.; Cherney, M.M.; Melton-Celsa, A.R.; Twiddy, E.M.; O’Brien, A.D.; James, M.N.G. Structure of Shiga toxin type 2 (Stx2) from Escherichia coli O157:H7. J. Biol. Chem. 2004, 279, 27511-27517. [CrossRef] [PubMed]

18. Stein, P.E.; Boodhoo, A.; Tyrrell, G.J.; Brunton, J.L.; Read, R.J. Crystal structure of the cell-binding B oligomer of verotoxin-1 from E. coli. Nature 1992, 355, 748-750. [CrossRef] [PubMed]

19. Ono, K.; Nakane, H.; Fukushima, M.; Chermann, J.C.; Barré-Sinoussi, F. Differential inhibitory effects of various flavonoids on the activities of reverse transcriptase and cellular DNA and RNA polymerases. Eur. J. Biochem. 1990, 190, 469-476. [CrossRef] [PubMed]

20. Ishige, K.; Schubert, D.S.Y. Flavonoids protect neuronal cells from oxidative stress by three distinct mechanisms. Free Radic. Biol. Med. 2001, 30, 433-446. [CrossRef] 
21. Wu, J.A.; Attele, A.S.; Zhang, L.; Yuan, C.S. Anti-HIV activity of medicinal herbs: Usage and potential development. Am. J. Chin. Med. 2001, 29, 69-81. [CrossRef] [PubMed]

22. Cao, Y.Y.; Dai, B.D.; Wang, Y.; Huang, S.; Xu, Y.G.; Cao, Y.B.; Gao, P.H.; Zhu, Z.Y.; Jiang, Y.Y. In vitro activity of baicalein against Candida albicans biofilms. Int. J. Antimicrob. Agent. 2008, 32, 73-77. [CrossRef] [PubMed]

23. Kuntz, S.; Wenzel, U.; Daniel, H. Comparative analysis of the effects of flavonoids on proliferation, cytotoxicity, and apoptosis in human colon cancer cell lines. Eur. J. Nutr. 1999, 38, 133-142. [CrossRef] [PubMed]

24. Pidgeon, G.P.; Kandouz, M.; Meram, A.; Honn, K.V. Mechanisms controlling cell cycle arrest and induction of apoptosis after 12-lipoxygenase inhibition in prostate cancer cells. Cancer Res. 2002, 62, 2721-2727. [PubMed]

25. Van, L.K.; Kim, H.Y.; Lee, S.R.; Jin, G.; Arai, K.; Lo, E.H. Baicalein and 12/15-lipoxygenase in the ischemic brain. Stroke 2006, 37, 3014-3018.

26. Ma, Z.; Otsuyama, K.I.; Liu, S.; Abroun, S.; Ishikawa, H.; Tsuyama, N.; Obata, M.; Li, F.-J.; Zheng, X.; Maki, Y. Baicalein, a component of Scutellaria radix from Huang-Lian-Jie-Du-Tang (HLJDT), leads to suppression of proliferation and induction of apoptosis in human myeloma cells. Blood 2005, 105, 3312-3318. [CrossRef] [PubMed]

27. Chao, J.-I.; Su, W.-C.; Liu, H.-F. Baicalein induces cancer cell death and proliferation retardation by the inhibition of CDC2 kinase and survivin associated with opposite role of p38 mitogen-activated protein kinase and AKT. Mol. Cancer Ther. 2007, 6, 3039-3048. [CrossRef]

28. Si, D.; Wang, Y.; Zhou, Y.H.; Guo, Y.; Wang, J.; Zhou, H.; Li, Z.-S.; Fawcett, J.P. Mechanism of CYP2C9 inhibition by flavones and flavonols. Drug Metab. Dispos. 2009, 37, 629-634. [CrossRef]

29. Dong, J.; Zhang, Y.; Chen, Y.; Niu, X.; Zhang, Y.; Li, R.; Yang, C.; Wang, Q.; Li, X.M.; Deng, X.M. Baicalin inhibits the lethality of ricin in mice by inducing protein oligomerization. J. Biol. Chem. 2015, 290, 12899-12907. [CrossRef]

30. Zhang, Y.; Qi, Z.; Liu, Y.; He, W.; Yang, C.; Wang, Q.; Dong, J.; Deng, X.M. Baicalin protects mice from lethal infection by enterohemorrhagic Escherichia coli. Front. Microbiol. 2017, 8, 2-7. [CrossRef]

31. Chiu, Y.W.; Lin, T.H.; Huang, W.S.; Teng, C.Y.; Liou, Y.S.; Kuo, W.H. Baicalein inhibits the migration and invasive properties of human hepatoma cells. Toxicol. Appl. Pharmacol. 2011, 255, 316-326. [CrossRef] [PubMed]

32. Oh, M.C.; Piao, M.J.; Fernando, P.M.D.J.; Han, X.; Hewage, S.R.K.M.; Park, J.E.; Ko, M.S.; Jung, U.; Kim, I.G.; Hyun, J.W. Baicalein protects human skin cells against ultraviolet B-induced oxidative stress. Biomol. Ther. 2016, 24, 616-622. [CrossRef] [PubMed]

33. Cariddi, L.N.; Sabini, M.C.; Escobar, F.M.; Montironi, I.; Mañas, F.; Iglesias, D.; Comini, L.R.; Sabini, L.I.; Dalcero, A.M. Polyphenols as possible bioprotectors against cytotoxicity and DNA damage induced by ochratoxin A. Environ. Toxicol. Pharmacol. 2015, 39, 1008-1018. [CrossRef] [PubMed]

34. Becker, G.L.; Lu, Y.; Hardes, K.; Strehlow, B.; Levesque, C.; Lindberg, I.; Sandvig, K.; Bakowsky, U.; Day, R.; Garten, W. Highly potent inhibitors of proprotein convertase furin as potential drugs for treatment of infectious diseases. J. Biol. Chem. 2012, 287, 21992-22003. [CrossRef] [PubMed]

35. Kavaliauskiene, S.; Dyvelingelem, A.B.; Skotland, T.; Sandvig, K. Protection against shiga toxins. Toxins 2017, 9, 1-25. [CrossRef] [PubMed]

36. Ertell, K. A review of toxicity and use and handling considerations for guanidine, guanidine hydrochloride, and urea. Pac. Northwest. Natl. Lab. 2006, 15747.

37. Tangtavorn, N.; Yospaiboon, Y.; Ratanapakorn, T.; Sinawat, S.; Sanguansak, T.; Bhoomibunchoo, C.; Laovirojjanakul, W. Incidence of and risk factors for chloroquine and hydroxychloroquine retinopathy in Thai rheumatologic patients. Clin. Ophthalmol. 2016, 10, 2179-2185. [CrossRef]

38. Cai, W.; Fu, Y.; Zhang, W.; Chen, X.; Zhao, J.; Song, W.; Li, Y.; Huang, Y.; Wu, Z.; Sun, R. Synergistic effects of baicalein with cefotaxime against Klebsiella pneumoniae through inhibiting CTX-M-1 gene expression. BMC Microbiol. 2016, 16, 1-9. [CrossRef]

39. Konowalchuk, J.; Dickie, N.; Stavric, S.; Speirs, J.I. Comparative studies of five heat-labile toxic products of Escherichia coli. Infect. Immun. 1978, 22, 644-6448.

40. Wagner, P.L.; Acheson, D.W.K.; Matthew, K.; Wagner, P.L.; Acheson, D.W.K. Human neutrophils and their products induce Shiga toxin production by enterohemorrhagic Escherichia coli. Infect. Immun. 2001, 69, 3-7. [CrossRef] 
41. Bergholz, T.M.; Wick, L.M.; Qi, W.; Riordan, J.T.; Ouellette, L.M.; Whittam, T.S. Global transcriptional response of Escherichia coli O157:H7 to growth transitions in glucose minimal medium. BMC Microbiol. 2007, 7, 1-27. [CrossRef] [PubMed]

42. Neely, M.N.; Friedman, D.I. Functional and genetic analysis of regulatory regions of coliphage H- 19B: Location of shiga-like toxin and lysis genes suggest a role for phage functions in toxin release. Mol. Microbiol. 1998, 28, 1255-1267. [CrossRef] [PubMed]

43. Wagner, P.L.; Livny, J.; Neely, M.N.; Acheson, D.W.K.; Friedman, D.I.; Waldor, M.K. Bacteriophage control of Shiga toxin 1 production and release by Escherichia coli. Mol. Microbiol. 2002, 44, 957-970. [CrossRef] [PubMed]

44. Yun, B.-Y.; Zhou, L.; Xie, K.-P.; Wang, Y.-J.; Xie, M.-J. Antibacterial activity and mechanism of baicalein. Acta Pharm. Sin. 2012, 47, 1587-1592.

45. Yuk, H.G.; Marshall, D.L. Adaptation of Escherichia coli O157:H7 to $\mathrm{pH}$ alters membrane lipid composition, verotoxin secretion, and resistance to simulated gastric fluid acid. Appl. Environ. Microbiol. 2004, 70, 3500-3505. [CrossRef] [PubMed]

46. Wu, T.; He, M.; Zang, X.; Zhou, Y.; Qiu, T.; Pan, S.; Xu, X.Y. A structure-activity relationship study of flavonoids as inhibitors of Escherichia coli by membrane interaction effect. Biochim. Biophys. Acta 2013, 1828, 2751-2756. [CrossRef] [PubMed]

47. Dinda, B.; Dinda, S.; DasSharma, S.; Banik, R.; Chakraborty, A.; Dinda, M. Therapeutic potentials of baicalin and its aglycone, baicalein against inflammatory disorders. J. Med. Chem. 2017, 131, 68-80. [CrossRef] [PubMed]

48. Li, Y.; Zhao, J.; Hölscher, C. Therapeutic potential of baicalein in Alzheimer's disease and Parkinson's disease. CNS Drugs 2017, 31, 639-652. [CrossRef]

49. Javed, H.; Ojha, S. Therapeutic potential of baicalein in Parkinson's disease: Focus on inhibition of $\alpha$-synuclein oligomerization and aggregation. Synucleins Biochem. Role Dis. 2019, 2019, 1-16.

50. Burnett, B.P.; Silva, S.; Mesches, M.H.; Wilson, S.; Jia, Q. Safety evaluation of a combination, defined extract of Scutellaria baicalensis and Acacia catechu. J. Food Biochem. 2007, 31, 797-825. [CrossRef]

51. Brooks, B.R.; Bruccoleri, R.E.; Olafson, B.D.; States, D.J.; Swaminathan, S.; Karplus, M. CHARMM: A program for macromolecular energy, minimization, and dynamics calculations. J. Comput. Chem. 1983, 4, 187-217. [CrossRef]

(C) 2019 by the authors. Licensee MDPI, Basel, Switzerland. This article is an open access article distributed under the terms and conditions of the Creative Commons Attribution (CC BY) license (http://creativecommons.org/licenses/by/4.0/). 